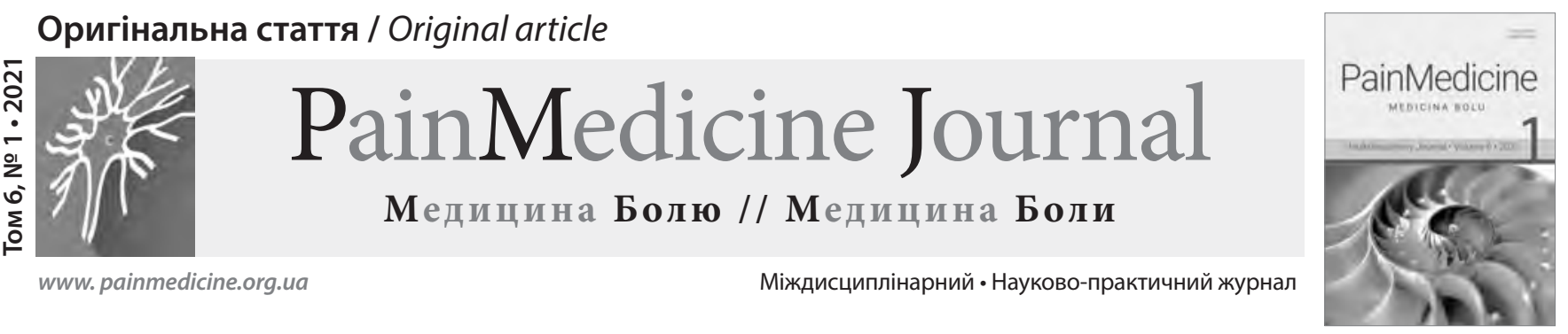

DOI: 10.31636/pmjua.v6i1.6

\title{
The effect of cryotherapy on pain during local and total application
}

\author{
Mašán J. ${ }^{1}$, Dobrovanov O. ${ }^{2,3}$, Čanecký A. ${ }^{1}$ \\ ${ }^{1}$ University of St. Cyril and Methodius in Trnava, Faculty of Health Sciences, Piešt'any, Slovakia \\ ${ }^{2}$ A. Getlík Clinic for Children and Adolescents, Slovak Medical University and University Hospital of Medicine, Bratislava, \\ Slovakia \\ ${ }^{3}$ Slovak Medical University, Bratislava, Slovakia
}

\begin{abstract}
Background: analgesic effect of total and local cryotherapy in people older than 55 years, in respondents with various diagnoses, most often with degenerative diseases, especially with gonarthrosis, coxarthrosis, spondylosis, osteoarthritis and polyarthrosis.

Objective: the aim of the survey was to process information from the field of total and local cryotherapy and to analyze the information obtained using questionnaires. We process the percentage effect of total and local cryotherapy on the intensity of painful symptoms, feeling, tolerance and satisfaction of respondents after completing ten therapies.
\end{abstract}

Materials and methods: the group of respondents consisted of 35 men and 65 women aged 55 to 81 years. A total of 100 respondents qualified for the survey. $50 \%$ of respondents participated in total cryotherapy and $50 \%$ of respondents participated in local cryotherapy.

Results: we processed the results using MS Excel and IBM SPSS. The Modified Laitinen Pain Questionnaire was used. Due to established hypotheses and the nature of the data, we used the Kolmogorov - Smirnov test, the nonparametric Mann - Whitney U-test and the Wilcoxon nonparametric test. The results show that with the help of local and total cryotherapy, the intensity of painful symptoms is lower.

Conclusions: the performed analysis of the data by means of a questionnaire showed that local and total cryotherapy alleviates pain and has an analgesic effect.

Key words: homiothermic being, vertebroalgic syndrome, Laitinen, vasodilation, vasoconstriction, total cryotherapy, local cryotherapy. 


\section{Introduction}

Significant advances in healthcare brought rising average life expectancy. Physiological and pathophysiological changes in the human body are associated with increasing age, as well as the frequency and incidence of various painful diseases (3). Physical treatment, which consists in the action of physical effects on the correct receptors, is recommended especially in the group of elderly patients due to the proven lower incidence, resp. absence of side effects $(2,8)$. Cryotherapy has an important place in physical therapy and therapy, because it is generally readily available and applicable to a wide range of diseases.

\section{Cryotherapy}

It is part of thermotherapy, which belongs to the branches of physical therapy, and consists essentially in the removal of heat from the body $(4,9)$. The physiological effects of cold treatment include reduction of pain, blood flow, swelling, inflammation, muscle cramps and metabolic demand. The analgesic effect of cryotherapy is to slow down the conduction of stimuli through nerve fibers and to reduce the irritability of receptors. If the pain is effectively managed, the patient may be able to begin and progress with therapy earlier to more quickly address range and strength deficits, as well as progress in full weight and function.

\section{Local cryotherapy}

Applying the effects of low temperatures to a certain part of the human body, a mixture of nitrogen vapor and cooled air ranging from $-100^{\circ} \mathrm{C}$ to $-178{ }^{\circ} \mathrm{C}$ or cooled air ranging from $-30{ }^{\circ} \mathrm{C}$ to $-34^{\circ} \mathrm{C}$. Cooling of the affected area and the immediate surroundings leads to blockage of skin nociceptors, which are connected to the connective tissue around the affected joints. In healthy tissue, transient vasoconstriction and subsequent vasodilation occur. Cold blockade of skin nociceptors leads to a reduced perception of pain at the affected site.

\section{Total cryotherapy}

It is defined as the stimulatory application of cryogenic temperatures (from $-100^{\circ} \mathrm{C}$ to $-160^{\circ} \mathrm{C}$ ) to the entire surface of the patient's body for a short time (1-3 minutes). Total cryotherapy (Whole Body Cryotherapy) affects the whole organism with different intensity, it causes biochemical, immunological and hormonal changes. Also, leaching of endorphins protects the body from stress, strengthens the performance of the immune system and induces euphoria. Last but not least, the efficiency, endurance and resilience of the central nervous system to fatigue and stress improve (1).

\section{Research}

The main goal was to analyze and evaluate the analgesic effect of local and total cryotherapy on pain in respondents older than 55 years, three hypotheses were established, which we examined.

Hypothesis 1: we assume that there is a statistically significant reduction in perceived pain on the Laitinen scale after 10 total cryotherapies.

Hypothesis 2: we assume that there is a statistically significant reduction in perceived pain on the Laitinen scale after 10 local cryotherapies.

Hypothesis 3: we assume that there is a statistically significant difference between local and total cryotherapy in the reduction of pain perception on the VAS scale after 10 cryotherapies.

\section{File characteristics}

100 respondents were included in the sample, of which 35 were men and 65 women. We qualify people of both sexes, aged 55 and over with symptoms of pain. $50 \%$ of respondents participated in total cryotherapy and $50 \%$ of respondents participated in local cryotherapy. Each respondent was admitted to the group on the basis of a previous medical examination, which qualifies him for local or total cryotherapy.

\section{Materials and methods}

The results were processed using MS Excel and IBM SPSS. The Laitinen Modified Pain Questionnaire was used. Due to established hypotheses and the nature of the data, we used the Kolmogorov-Smirn normality test, the nonparametric Mann-Whitney U-test and the Wilcoxon nonparametric paired test.

The values in the Table 1 express how many times a given response occurs in 50 respondents in total cryotherapy and in 50 respondents in local cryotherapy. These are the results of the scoring of the questionnaire, then they were evaluated and a conversion to a percentage improvement was performed.

Percentage improvement was calculated as the difference before and after the therapy relative to the pre-therapy state in percent, i.e. $(x-y) / x * 100$, where $x$ is the pre-therapy condition, $y$ is the post-therapy condition.

Hypothesis 1: we assume that there is a statisticalIy significant reduction in perceived pain on the Laitinen scale after 10 total cryotherapies.

Based on the results of the Wilcoxon paired test, we can state that the perception of pain on the Laitinen scale decreased statistically significantly after 10 total cryotherapies. Hypothesis 1 was therefore confirmed (Tables 2, 3; Fig. 1, 2). 
Table 1. Interpretation of the questionnaire on modified pain according to Laitinen - results of interpretation:

\begin{tabular}{|c|c|c|c|c|c|c|}
\hline \multirow[t]{2}{*}{ Intensity of pain } & \multirow[t]{2}{*}{$N=100$} & \multirow[t]{2}{*}{$\%$} & \multicolumn{2}{|c|}{ Total cryotherapy } & \multicolumn{2}{|c|}{ Local cryotherapy } \\
\hline & & & $\mathrm{N}=50$ & $\%$ & $\mathrm{~N}=50$ & $\%$ \\
\hline No improvement $0 \%$ & 35 & 35 & 21 & 42 & 14 & 28 \\
\hline Unsatisfactory improvement 1-24 \% & 0 & 0 & 0 & 0 & 0 & 0 \\
\hline Satisfactory improvement $25-49 \%$ & 8 & 8 & 5 & 10 & 3 & 6 \\
\hline Good improvement 50-74 \% & 41 & 41 & 17 & 34 & 24 & 48 \\
\hline Very good improvement $75-100 \%$ & 16 & 16 & 7 & 14 & 9 & 18 \\
\hline Frequency of pain & $N=100$ & $\%$ & $N=50$ & $\%$ & $\mathrm{~N}=50$ & $\%$ \\
\hline No improvement $0 \%$ & 36 & 36 & 25 & 50 & 11 & 22 \\
\hline Unsatisfactory improvement 1-24 \% & 0 & 0 & 0 & 0 & 0 & 0 \\
\hline Satisfactory improvement $25-49 \%$ & 6 & 6 & 1 & 2 & 5 & 10 \\
\hline Good improvement $50-74 \%$ & 43 & 43 & 18 & 36 & 25 & 50 \\
\hline Very good improvement $75-100 \%$ & 15 & 15 & 6 & 12 & 9 & 18 \\
\hline Use of painkillers & $N=69$ & $\%$ & $\mathrm{~N}=32$ & $\%$ & $\mathrm{~N}=37$ & $\%$ \\
\hline No improvement $0 \%$ & 32 & 46,38 & 17 & 53,13 & 15 & 40,54 \\
\hline Unsatisfactory improvement $1-24 \%$ & 0 & 0 & 0 & 0 & 0 & 0 \\
\hline Satisfactory improvement $25-49 \%$ & 1 & 1,45 & 1 & 3,13 & 0 & 0 \\
\hline Good improvement $50-74 \%$ & 12 & 17,39 & 4 & 12,50 & 8 & 21,62 \\
\hline Very good improvement $75-100 \%$ & 24 & 34,78 & 10 & 31,25 & 14 & 37,84 \\
\hline Restriction of physical activity & $N=91$ & $\%$ & $\mathrm{~N}=41$ & $\%$ & $\mathrm{~N}=50$ & $\%$ \\
\hline No improvement $0 \%$ & 52 & 57,14 & 30 & 73,2 & 22 & 44 \\
\hline Unsatisfactory improvement $1-24 \%$ & 0 & 0 & 0 & 0 & 0 & 0 \\
\hline Satisfactory improvement $25-49 \%$ & 3 & 3,30 & 0 & 0 & 3 & 6 \\
\hline Good improvement $50-74 \%$ & 18 & 19,78 & 6 & 14,6 & 12 & 24 \\
\hline Very good improvement $75-100 \%$ & 18 & 19,78 & 5 & 12,2 & 13 & 26 \\
\hline
\end{tabular}

Table 2. Perception of pain before total cryotherapy (Laitinen)

\begin{tabular}{ll}
\hline $\mathrm{N}$ & 50 \\
\hline Average & 5,92 \\
\hline Median & 6,00 \\
\hline Standard deviation & 2,791 \\
\hline Slopingness & 0,713 \\
\hline Pointing & 1,420 \\
\hline Margin & 13 \\
\hline Minimum & 1 \\
\hline Maximum & 14 \\
\hline
\end{tabular}

Table 3. Perception of pain after total cryotherapy (Laitinen)

\begin{tabular}{ll}
\hline $\mathrm{N}$ & 50 \\
\hline Average & 3,82 \\
\hline Median & 3,00 \\
\hline Standard deviation & 2,663 \\
\hline Slopingness & 1,053 \\
\hline Pointing & 1,861 \\
\hline Margin & 12 \\
\hline Minimum & 0 \\
\hline Maximum & 12 \\
\hline
\end{tabular}




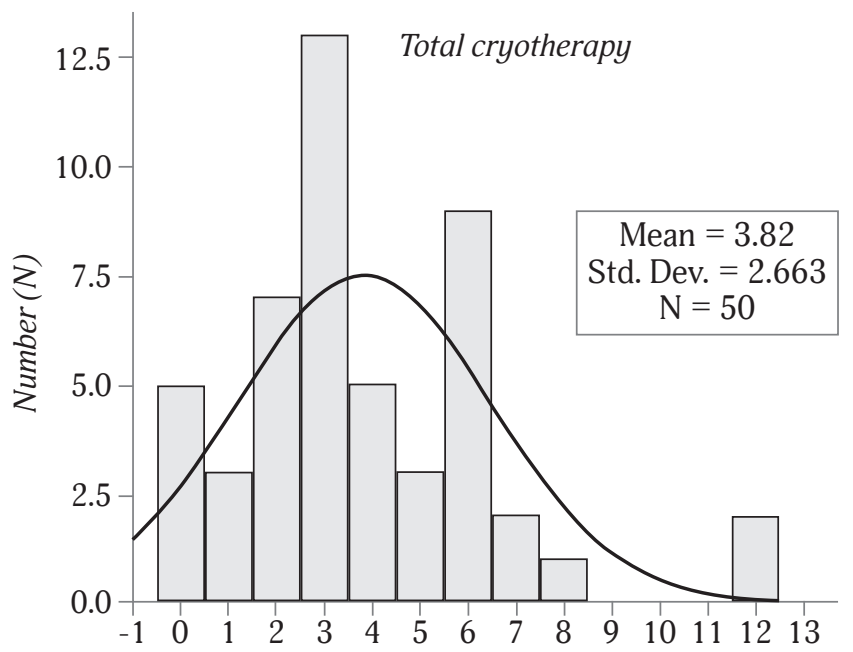

Fig. 1. Perception of pain before total cryotherapy (Laitinen)

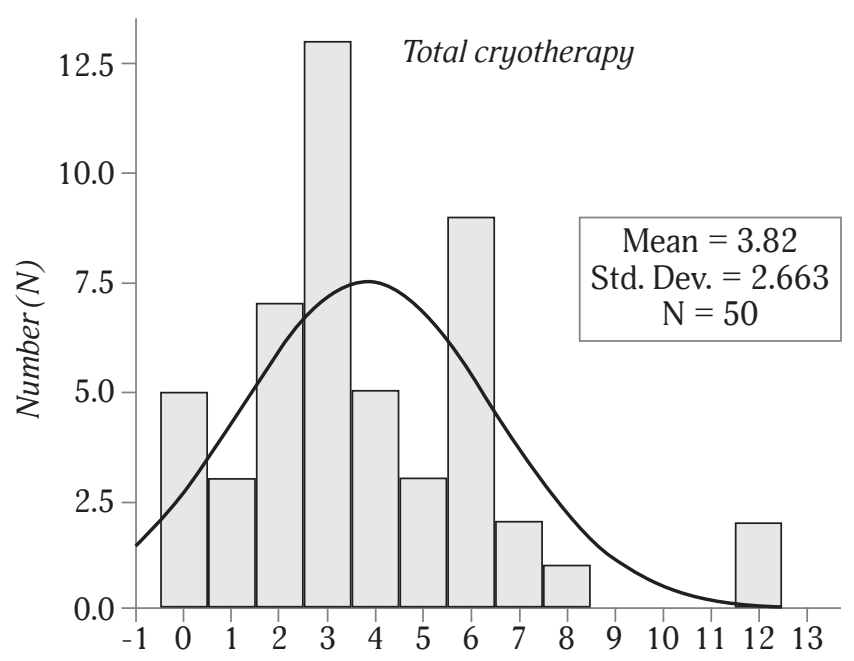

Fig. 2. Perception of pain after total cryotherapy (Laitinen)

Hypothesis 2: we assume that there is a statistically significant reduction in perceived pain on the Laitinen scale after 10 local cryotherapies.

Based on the results of the Wilcoxon paired test, we can state that the perception of pain on the Laitinen scale decreased statistically significantly after 10 local cryotherapies. Hypothesis 2 was confirmed (Tables 4, 5; Fig. 3, 4).

Hypothesis 3: we assume that there is a statistically significant difference between local and total cryotherapy in the reduction of pain perception on the VAS scale after 10 cryotherapies.

For hypothesis analysis, we used a nonparametric Mann-Whitney U-test for 2 independent selections, taking into account tests of distribution normality and the nature of variables.

Based on the results, we can state that there is a statistically significant difference between local and total cryo-
Table 4. Perception of pain before local cryotherapy (Laitinen)

\begin{tabular}{ll}
\hline $\mathrm{N}$ & 50 \\
\hline Average & 7,46 \\
\hline Median & 7,00 \\
\hline Standard deviation & 2,597 \\
\hline Slopingness & 0,139 \\
\hline Pointing & $-1,173$ \\
\hline Margin & 9 \\
\hline Minimum & 3 \\
\hline Maximum & 12 \\
\hline
\end{tabular}

Table 5. Perception of pain after local cryotherapy (Laitinen)

\begin{tabular}{ll}
\hline $\mathrm{N}$ & 50 \\
\hline Average & 4,14 \\
\hline Median & 3,50 \\
\hline Standard deviation & 2,755 \\
\hline Slopingness & 0,787 \\
\hline Pointing & 0,204 \\
\hline Margin & 10 \\
\hline Minimum & 0 \\
\hline Maximum & 10
\end{tabular}

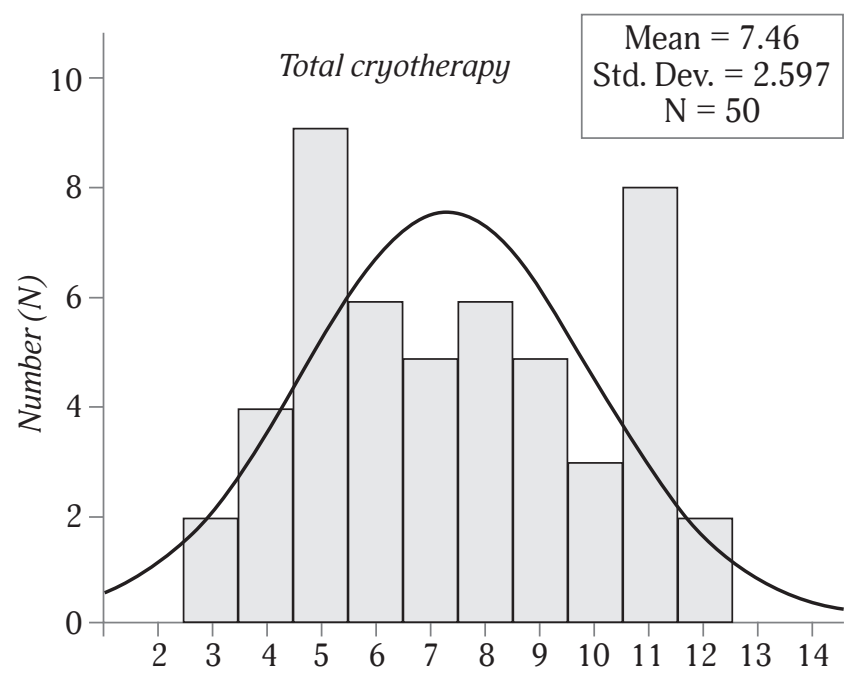

Fig. 3. Perception of pain before local cryotherapy (Laitinen) 


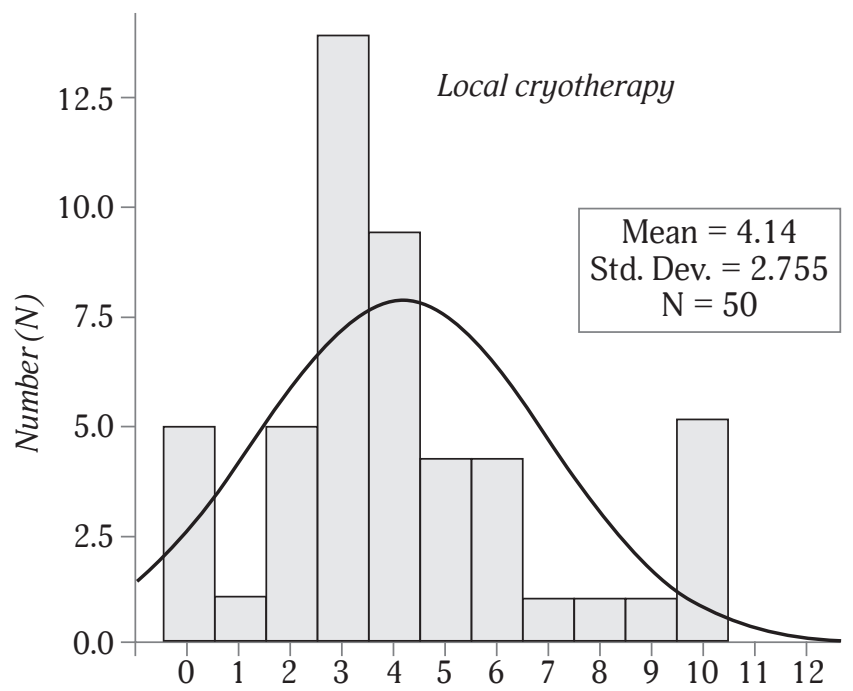

Fig. 4. Perception of pain after local cryotherapy (Laitinen)

therapy in the percentage of pain reduction on the VAS scale after 10 cryotherapies. In particular, total cryotherapy reduced pain on a VAS scale statistically significantly more than local cryotherapy. Hypothesis 3 was confirmed (Tables 6, 7; Fig. 5, 6).

\section{Discussion}

Research suggests that the incidence of pain increases with age. The most common chronic pains, such as osteoarthritis or back pain, are so common that they are often considered a normal part of life (7). Chronic pain causes a complex set of physical and psychosocial changes that burden the respondent. Numerous scientific studies on the effect of cryogenic temperatures on the human body have shown that cryotherapy is a safe, effective and well-tolerated method of physiotherapy. It confirms the analgesic, anti-inflammatory and anti-edema effects of

Table 6. Percentage reduction in initial pain (VAS) after cryotherapy Total cryotherapy

\begin{tabular}{ll}
\hline $\mathrm{N}$ & 50 \\
\hline Average & 30,5000 \\
\hline Median & 21,0000 \\
\hline Standard deviation & 33,22173 \\
\hline Slopingness & 0,698 \\
\hline Pointing & $-0,879$ \\
\hline Margin & 100,00 \\
\hline Minimum & 0,00 \\
\hline Maximum & 100,00 \\
\hline
\end{tabular}

Table 7. Percentage reduction of original pain (VAS) after cryotherapy Local cryotherapy

\begin{tabular}{ll}
\hline $\mathrm{N}$ & 50 \\
\hline Average & 59,2000 \\
\hline Median & 65,0000 \\
\hline Standard deviation & 30,25807 \\
\hline Slopingness &,- 669 \\
\hline Pointing &,- 625 \\
\hline Margin & 100,00 \\
\hline Minimum &, 00 \\
\hline Maximum & 100,00 \\
\hline
\end{tabular}

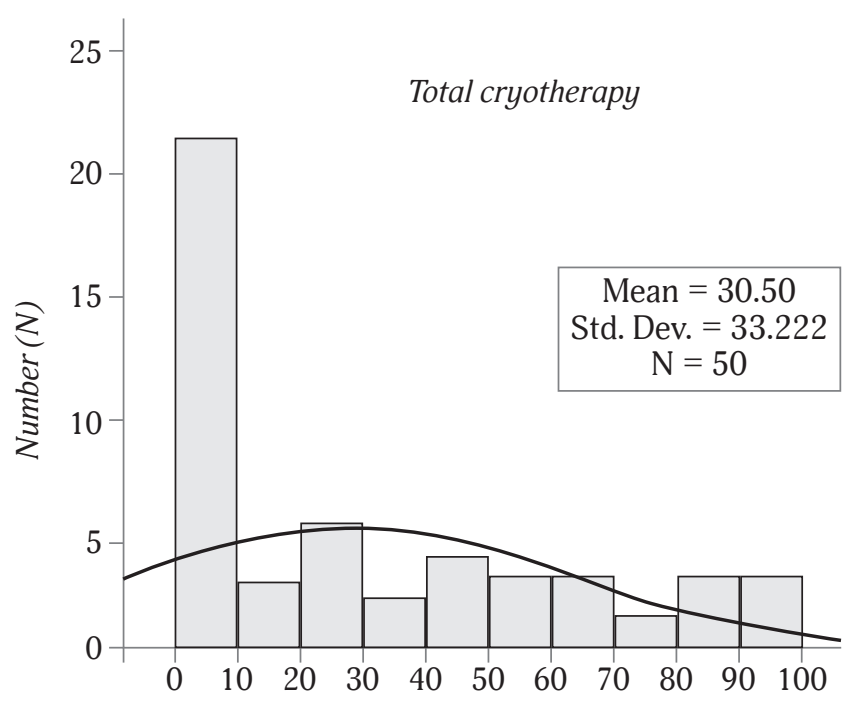

Fig. 5. Percentage reduction in initial pain (VAS) after cryotherapy (Total cryotherapy)

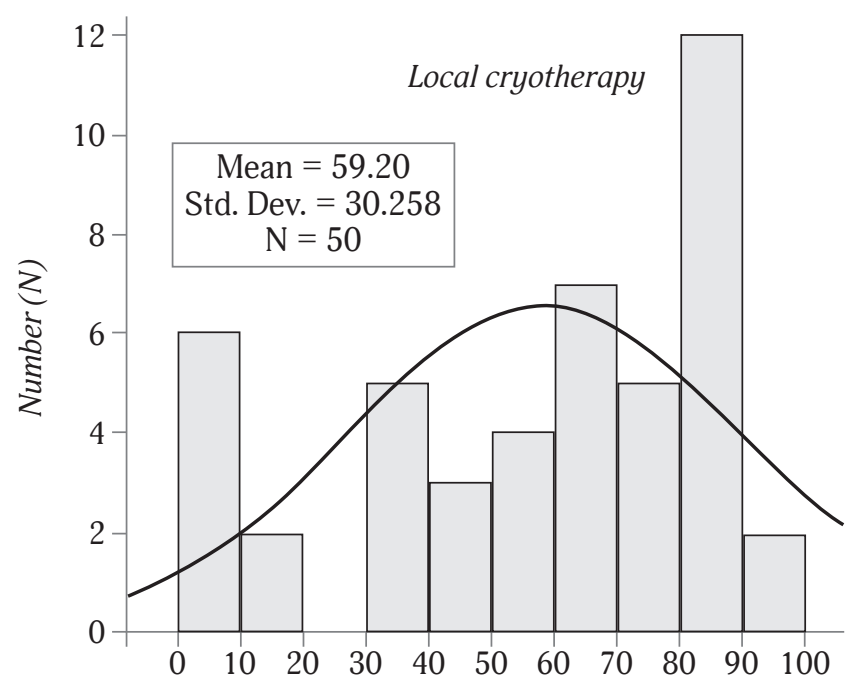

Fig. 6. Percentage reduction of original pain (VAS) after cryotherapy (Local cryotherapy) 
cryotherapy, as well as its beneficial effect on the mental state. Data collection took place at the workplace, which had specialized equipment for performing total cryotherapy - cryogenic chamber and equipment for performing local cryotherapy.

Respondents most often reported degenerative diseases, especially gonarthrosis, coxarthrosis, spondylosis and polyarthritis. Osteoarthritis is the most common disease of the musculoskeletal system and its incidence increases with age. When asked whether painkillers were used after cryotherapy, $21 \%$ of respondents answered in the affirmative. The pain was not as much lowered as to give up painkillers. However, in $42.86 \%$ of respondents taking painkillers after cryotherapy, the dose was much lower after a series of ten treatments. As many as $74 \%$ of respondents declared their sense of satisfaction and well-being after cryotherapy. Satisfaction with the effects of treatment obtained after cryotherapy was expressed positively by the vast majority of respondents. As many as $64 \%$ of respondents said they were satisfied, $31 \%$ of respondents said they were very satisfied. This satisfaction may be the result of reducing, alleviating or even eliminating the pain experienced (5).

A revised Laitinen pain assessment questionnaire indicated the following conclusions: $65 \%$ of respondents achieved an improvement, while $35 \%$ of respondents did not improve significantly. Thanks to the Laitinen questionnaire, we can describe the respondent's pain in a more thorough and better way. Compared to the VAS scale, Laitinen is more complex in assessing pain attributes. In respondents with limited physical activity due to the analgesic effect of cryotherapy, the restriction was reduced by at least a quarter. The dose of pain medication during the cryotherapy series decreased in $63.89 \%$ of respondents.

\section{Conclusions}

One usually perceives the smooth functioning of one's body as something self-evident. But with health problems, it seems that the quickest and simplest solution leads pri- marily to the use of painkillers, but of course they also have side effects. The results of the analysis of the data collected through the questionnaire showed that local and total cryotherapy in our respondents alleviates pain and has an analgesic effect. Cryotherapy also had an effect on the feeling of well-being. The vast majority of them observed an improvement in their condition after therapy. Respondents also noted that after several therapies, the coldness was progressively less pronounced, improving their tolerance to low temperatures (6). It supports the treatment of injuries and other diseases and has a general effect on strengthening the body and its immunity.

\section{References}

1. Bettany-Saltikov J, editor. Physical Therapy Perspectives in the 21st Century - Challenges and Possibilities. InTech; 2012 Apr 5; Available from: https://doi.org/10.5772/2257

2. Dinka P. et al. Voda a chlad: prevencia, liečba, rehabilitácia. Bratislava: Formát. 2008: 313 p. ISBN 9788096722952.

3. Dmytriiev D, Glazov E, Zaletskiy B, Dmytriiev K, Dobrovanov O, Králinský K. A new modifed technique of combined intramuscular quadratum lumborum block and it's effectiveness. Lek. Obzor. Herba; 2020;69(9):285-291.

4. Grenzmann D. Kryotherapie und Hypothermie: Anwendungsgebiete, Kryochirurgie, Kältekammer. Verlag: Munchen GRIN; 2010. 26 p.

5. Gúth A. Bolest' - priatel' alebo nepriatel'. Rehabilitácia; 2019;56(4):2-3.

6. Hasa P. Analysis of socio-economic aspects of the Quality of life of seniors in Slovakia. International Journal of Health, New Technologies and Social Work (Zdravotníctvo a sociálna práca / Health and Social Work); 2019;14(1):40-52.

7. Ludvigh Cintulová L. Beňo P (2019). Risk of Burn Out Syndrome in Health Care and Social Services . Health and Social Work; 2019;14(2):70-75.

8. Łukasik A, Barylski M, Irzmański R. Rehabilitacja osób w wieku podeszłym - terapia z wyboru dla starzejącego się społeczeństwa. In: Geriatria; 2019;5:315-323. Available at: http://www.akademiamedycyny.pl/wpcontent/uploads/ 2016/05/201104_Geriatria_008.pdf.

9. Madejski R, Madejski E. Krioterapia - lecznicze zimno. In: Lider; 2010;6:11-3. 
Влияние криотерапии на боль при ее локальном и общем применении

${ }^{1}$ Университет Св. Кирилла и Мефодия в Трнаве, факультет медицинских наук, Пьештяны, Словакия

${ }^{2}$ Детская и подростковая клиника А. Гетлика, Словац кий медицинский университет, Университетская клиника, Братислава, Словакия

${ }^{3}$ Словацикий медицинский университет, Братислава, Словакия

\section{Резюме}

Обоснование: обезболивающий эффект общей и локальной криотерапии у людей старше 55 лет, у респондентов с различными диагнозами, чаще всего с дегенеративными заболеваниями, особенно при гонартрозе, коксартрозе, спондилезе, остеоартрозе и полиартрозе.

Цель работы: цеелью исследования было обработать информацию о применении тотальной и локальной криотерапии и проанализировать информацию,, полученную с помощью анкет. Мы обрабатываем процентнное влияние общей и локальной криотерапии на интенсивность болезненных симптомов, ощущения, терпимость и удовлетворенность респондентов после завершения десяти процедур.

Материалы и методы: группа респондентов состояла из 35 мужчин и 65 женщзин в возрасте от 55 до 81 года. В опросе приняли участие 100 респондентов. 50\% респондентов получали общую криотерапию и $50 \%$ респондентов получали локальную криотерапию.

Результаты: мы обработали результаты с помощью MS Exсеl и IBM SPSS. Использовался Модифицированный опросник Лайтинен о боли. Ввиду установленных гипотез и характера данных мы использовали Критерий однородности Колмогорова - Смирнова, статистический U-критерий Манна - Уитни и критерий знаковых рангов Вилкоксона. Результаты показывают, что с помощью локальной и общей криотерапии выраженность болезненных симптомов снижается.

Заключение: проведенный анализ данных с помощью вопросника показал, что локальная и общзая криотерапия облегчает боль и обладает обезболивающим действием.

Ключевые слова: гомотермическое существо, вертеброгенный болевой синдром, Лайтинен, вазодилатацุия, вазоконстрикции, общая криотерапия, локальная криотерапия.
Вплив кріотерапії на біль при ї̈ локальному і загальному застосуванні

Mašán J. ${ }^{1}$ Dobrovanov O. ${ }^{2,3}$, Čanecký $A .{ }^{1}$

${ }^{1}$ Університет св. Кирила і Мефодія в Трнаві, факультет наук про здоров'я, П'єштяни, Словаччина

${ }^{2}$ Клініка для дітей та підлітків А. Гетліка, Словацький медичний університет, Університетська клініка, Братислава, Словаччина

${ }^{3}$ Словацьвий медичний університет, Братислава, Словаччина

Резюме

Обгрунтування: знеболюючий ефект загальної та локальної кріотерапії у людей старше 55 років, у респондентів з різними діагнозами, найчастіше з дегенеративними захворюваннями, особливо при гонартрозі, коксартрозі, спондильозі, остеоартрозі й поліартрозі.

Мета роботи: метою дослідження було опраццювати інформацію про застосування тотальної і локальної кріотерапії та проаналізувати інформацію, отриману за допомогою анкет. Ми обробляємо процентний вплив загальної та локальної кріотерапії на інтенсивність хворобливих симптомів, відчуття, терпимість і задоволеність респондентів після завершення десяти процеедур.

Матеріали і методи: група респондентів складалася з 35 чоловіків і 65 жінок у віці від 55 до 81 року. В опитуванні взяли участь 100 респондентів. $50 \%$ респондентів отримували загальну кріотерапію і 50\% респондентів отримували локальну кріотерапію.

Результати: ми опрацювали результати за допомогою MS Exсеl і IBM SPSS. Використовувався Модифікований опитувач Лайтінен про біль. 3 огляду на встановлені гіпотези і характер даних ми використовували Критерій узгодженості Колмогорова - Смирнова, статистичний U-критерій Манна - Уітні та критерій знакових рангів Вілкоксона. Результати показують, щзо за допомогою локальної і загальної кріотерапії вираженість хворобливих симптомів знижується.

Висновки: проведений аналіз даних за допомогою опитувача показав, що локальна і загальна кріотерапія полегшує біль і має знеболюючу дію.

Ключові слова: гоміотермічна істота, вертеброгенний больовий синдром, Лайтінен, вазодилатація, вазоконстрикція, загальна кріотерапія, локальна кріотерапія. 